\title{
PENINGKATAN KOMPETENSI SISWA MELALUI KOMPETISI SAINS
}

\author{
Khoirul Farida1, Yuyun E. Zuhroh², Dian S. N. Afifah ${ }^{3}$, Rahyu Setiani' \\ Abdul Manaf ${ }^{5}$ \\ 1,3,4,5 Universitas Bhinneka PGRI Tulungagung \\ ${ }^{2}$ MTsN 2 Tulungagung \\ email korespondensi : sifaramadhani80@gmail.com
}

\begin{abstract}
Diterima : (23-10-2020), Revisi: (03-12-2020), Diterbitkan : (24-12-2020)
ABSTRAK

Kualitas pendidikan dalam pembelajaran Matematika menjadi salah satu acuan persaingan intelektualitas antar Negara. Salah satu upaya pemerintah dalam peningkatan intelektualitas adalah dengan mengadakan Kompetisi Sains Madrasah (KSM). Berbagai upaya dilakukan guru terhadap peningkatan kompetensi mtematika siswa melalui KSM, salah satunya dengan pembinaan KSM di sekolah-sekolah. Artikel ini bertujuan untuk mendeskripsikan bentuk pembinaan KSM di Indonesia sebagai upaya meningkatkan kompetensi siswa. Metodologi yang digunakan dalam penulisan artikel ini adalah penelitian lapangan (field reserch) di MTsN 2 Tulungagung dan studi kepustakaan (field research) yang diperoleh dari jurnal penelitian tentang pembinaan olimpiade di Indonesia. Hasil studi ini menemukan berbagai bentuk metode pembinaan yang variatif, lebih menyenangkan dan dapat diserap oleh siswa serta menunjang peningkatan kompetensi di bidang Matematika, diantaranya bentuk pembinaan intensif mandiri, pretest-treatment-postest, kelompok (study club) rutin, dan kelas olimpiade serta pengembangan bahan ajar yang lebih berkualitas.
\end{abstract}

Kata Kunci : Kompetensi Siswa, Kompetisi Sains Madrasah (KSM) 


\begin{abstract}
Quality of education in mathematics studies is one of the references for intellectual competition between countries. One of the government's efforts to increase intelectuality is holding Kompetisi Sains Madrasah (KSM). Various efforts have been made by the teacher to improve students' mathematical competence through KSM, one of which is by fostering KSM in schools. This article aims to describe the form of KSM guidance in Indonesia as an effort to improve student competency. The methodology used in this article is filed research at MTsN 2 Tulungagung and library research from the journals about olympiad guidance in Indonesia. Conclussion of this study find of some varied guidence method, more enjoyable and can be absorbed by students and support to increase the Mathematic competence, like form of intensive independent guidance, pretest-treatment-postest, study club, olympiad classes and developing for material more quality.
\end{abstract}

Keywords : Student Competence, KSM.

\title{
Pendahuluan
}

Pengembangan bidang pendidikan menjadi salah satu penentu kesuksesan suatu negara dalam melakukan persaingaan antar negara. Pendidikan menjadi acuan perkembangan generasi sepuluh tahun ke depan dalam kemajuan bangsa. Sumber daya manusia tidak terlepas dari pendidikan, karena pendidikan akan meningkatkan kemampuan daya nalar, kreativitas dan berpikir kritis sehingga menjadikan manusia siap bersaing. Begitupun kompetensi siswa merupakan tujuan utama dalam pembelajaran baik yang akan berguna untuk pendidikan lanjutan, karir ataukehidupan sehari-hari siswa. Siswa sebagai generasi penerus penentu pendidikan harus menjadi pemikir yang kritis, jujur dan bermartabat, sehingga mampu menghadapi berbagai tantangan dan dapat bertahan hidup secara manusiawi dengan penuh rasa percaya diri (Wiyoko, dkk., 2019).

Pengembangan pendidikan di Indonesia mencangkup berbagai bidang, utamanya sains dan matematika. Matematika menjadi salah satu pelajaran wajib pendidikan formal di Indonesia, mulai pada lembaga pendidikan dasar hingga lembaga pendidikan tinggi. Pembelajaran matematika di SMP/ MTS termasuk dalam mata pelajaran umum kelompok A yang muatan dan acuannya dikembangkan oleh pusat (Permendikbud No.35 Tahun 2018, 2018). Matematika juga merupakan mata pelajaran berguna bagi kehidupan sehari hari sesuai fungsi matematika yaitu matematika merupakan suatu alat yang digunakan untuk mengembangkan cara berfikir (Fahrurazi \& Hamdi, 2017). Selain itu matematika juga membantu manusia dalam 
memahami dan menguasai permasalahan sosial, ekonomi, dan alam sekitar.

Implementasi pembelajaran matematika masa ini telah mengedepankan konsep pembelajaran aktif dengan Kurikulum 2013. Kurikulum 2013 memandang karakter bangsa menjadi unsur utama pengembangan kepribadian siswa. Kompetensi Inti yang harus dicapai siswa sesuai dengan Kurikulum 2013 mencakup sikap spiritual, kepribadian, pengetahuan dan ketrampilan; yaitu mengolah, menalar, dan menyaji dalam ranah konkret dan ranah abstrak terkait dengan pengembangan dari hal-hal yang dipelajari di sekolah secara mandiri, dan mampu menggunakan metode sesuai kaidah keilmuan. Pembelajaran matematika selalu terkait dengan objek matematika yang abstrak. Bell menyatakan bahwa objek langsung dalam matematika adalah fakta, konsep, prinsip dan operasi/aturan. Untuk mempelajari semua objek matematika tersebut dibutuhkan tata nalar yang baik, proses abstraksi, dan proses kognitif yang baik (Jana, 2018b).

Salah satu upaya pemerintah dalam rangka peningkatan kualitas sumber daya manusia dalam aspek pendidikan terutama matematika, dilakukan dengan mengadakan Kompetisi Sains Madrasah (KSM) yang telah dirintis sejak tahun 2012. Program ini merupakan salah satu wadah strategis untuk mengembangkan daya nalar, kemampuan memecahkan masalah, kreativitas, dan sportivitas siswa. Secara umum Kompetisi Sains Madrasah (KSM) bertujuan untuk peningkatkan mutu pendidikan Sains di madrasah/sekolah secara komprehensif melalui penumbuhkembangan budaya belajar, kreativitas, dan motivasi meraih prestasi terbaik dalam ridha Allah SWT dengan kompetisi yang sehat dan menjunjung tinggi sportivitas dan nilai-nilai Islam dalam mempelajari dan memahami sains (Kemenag RI, 2016). Pelaksanaan KSM secara berkelanjutan akan berdampak positif pada peningkatan mutu pendidikan dan pembelajaran sehingga siswa memiliki daya juang yang tinggi, kompetitif dan inovatif.

Upaya pemerintah dalam jangka panjang terkait pelaksanaan KSM tersebut seharusnya direspon dengan baik oleh lembaga pendidikan. Tetapi pada kenyataannya sekolah hanya mengajukan siswa yang memiliki prestasi belajar yang baik saja untuk mengikuti kompetisi tersebut, termasuk pada mata pelajaran Matematika. Hanya sebagian dari siswa yang memiliki kompetensi yang baik dalam pembelajaran matematika yang terpilih untuk ikut dalam kegiatan tersebut. Penilaian dari Program for International Student Assessment (PISA) menunjukkan bahwa pencapaian siswa Indonesia untuk sains, membaca, dan matematika masih me- 
nempati peringkat 62, 61, dan 63 dari 69 negera. Artinya Literasi sains siswa di Indonesia masih tergolong rendah. Dengan demikian, diperlukan kompetensi Matematika siswa yang tinggi untuk dapat mengikuti kegiatan KSM matematika dengan baik dan memperoleh hasil yang memuaskan (Wiyoko, dkk., 2019).

Kegitan KSM akan memberikan gambaran atau pemantapan kompetensi siswa di sekolah. Hasil KSM yang telah diikuti sebelumnya dapat menjadi evaluasi tentang seberapa taraf kompetensi siswa dalam bidang matematika di sekolah tesebut. Hasil tersebut akan mempengaruhi kualitas dan mutu lembaga pendidikan sesuai eksistensinya. Dalam peningkatan kemampuan siswa mata pelajaran Matematika sebagai tujuan utama, perlu adanya upaya kreatif dari guru di wilayah Indonesia utamanya berkaitan dengan persiapan siswa dalam mengikuti lomba KSM maupun pembelajaran di kelas. Dengan demikian, diperlukan kompetensi matematika siswa yang tinggi untuk dapat mengikuti kegiatan KSM matematika dengan baik.

Penelitian yang relevan dengan artikel ini berjudul peningkatan kompetensi siswa melalui pembinaan olimpiade sains (OSN), menunjukkan bahwa pembinaan sains memberikan pengaruh baik dalam persiapan OSN dalam bentuk antusias dan semangat. Hasil penelitian mengindikasikan siswa yang pengetahuannya bertambah secara signifikan sebesar $40 \%$ atau 4 orang, siswa yang memiliki kemampuan keterampilan menyelesaikan soal-soal sebesar 30\% atau 3 orang, dan siswa yang memiliki kemampuan menganalisis soal sebesar 20\% atau 2 orang (Wiyoko, dkk., 2019). Penelitian Ariyanti, dkk. (2019) menunjukkan bahwa peningkatan kompetensi matematika dapat dilakukan dengan pemberdayaan klub Matematika dan IPA di kota Madiun secara rutin. Penelitian-penelitian tersebut menjadi penelitian awal untuk mendukung adanya pembuatan artikel ilmiah ini. Penelitian ini difokuskan pada variasi pembinaan yang ada di Indonesia dan urgensinya dalam peningkatan kompetensi matematika. Untuk itu akan dilakukan penelaahan terhadap peningkatan kompetensi siswa pada mata pelajaran Matematika di Indonesia melalui KSM.

\section{Metode Penelitian}

Artikel ini menggunakan pendekatan kualitatif (qualitatif research) yang konsep data dianalisis dan dipaparkan dengan kata-kata. Adapun jenis penelitian yang di- 
gunakan adalah penelitian lapangan (field research) dari MTsN 2 Tulungagung dan penelitian kepustakaan (library research). Data penelitian dikumpulkan dari MTsN 2 Tulungagung dan data kepustakaan yang berupa jurnal-jurnal penelitian terdahulu di Indonesia yang relevan dengan kegiatan peningkatan kompetensi dalam pembinaan olimpiade sains di Indonesia pada kisaran tahun kurang lebih 5 tahun terakhir. Selanjutnya data-data tersebut dipilah serta dipilih yang relevan untuk dianalisis sehingga diperoleh 5 sistem pembinaan kompetisi dan olimpiade dengan metode, strategi, pengembangan media dan praktik lapangan dalam meningkatkan kompetensi matematika menjadi aktual, maksimal dan sesuai dengan keadaan saat ini. Analisis data dilakukan dengan proses reduksi, penyajian, konklusi dan diverifikasi, kemudian disusun secara sistematis. Pengecekan keabsahan data dilakukan dengan triangulasi dan diskusi teman sejawat.

\section{Hasil dan Pembahasan}

\section{Pembelajaran Matematika}

Kata Pembelajaran adalah terjemahan dari "Instruction" yang banyak dipakai dalam dunia pendidikan di Amerika Serikat. Kata "Instruction" dipengaruhi oleh aliran psikologi kognitif-wholistik yang menempatkan siswa sebagai sumber dari kegiatan. Selain itu, istilah ini juga diasumsikan dapat mempermudah siswa mempelajari segala sesuatu lewat berbagai macam media seperti bahan-bahan cetak, program televisi, gambar, audio dan lain sebagainya, sehingga semua itu mendorong terjadinya perubahan peranan guru dalam mengelola proses pembelajaran, dari guru sebagai sumber belajar menjadi guru sebagai fasilitator dalam pembelajaran (Fathurrohman, 2017).

Istilah Matematika berasal dari perkataan latin mathematica, yang mulanya diambil dari perkataan Yunani mathematike, yang berarti relating to learning, yang memiliki akar kata mathemati yang berarti pengetahuan atau ilmu dan berhubungan erat dengan sebuah kata lain yang serupa yaitu mathanein yang mengandung arti belajar atau berfikir. Matematika adalah telaah tentang pola dan hubungan, suatu jalan pola berfikir, suatu seni, suatu bahasa dan suatu alat. Pembelajaran matematika adalah proses interaksi antara guru dengan siswa mempelajari tentang pola dan struktur, analisa logis, dan perhitungan dengan pola dan struktur lewat berbagai macam metode, media sehingga mendorong terjadinya perubahan 
perilaku siswa sehingga semua itu mendorong terjadinya perubahan peranan guru dalam mengelola proses pembelajaran, dari guru sebagai sumber belajar menjadi guru sebagai fasilitator dalam pembelajaran

\section{Kompetensi Siswa dalam Mata Pelajaran Matematika}

Kompetensi siswa sangat berkaitan dengn penggunaan kurikulum dalam lembaga pendidikan. Sesuai dengan kenyataan bahwa kurikulum yang diberlakukan di Indonesia adalah kurikulum 2013 yang telah mengalami beberapa revisi dewasa ini. Pengertian kurikulum sendiri muncul pertama kali pada kamus Webster pada tahun 1856, yang digunakan dalam bidang olahraga, yang berarti jarak yang ditempuh oleh pelari atau kereta dari start sampai finish (Zaini, 2009). Pada tahun 1955 kata kurikulum muncul khusus digunakan dalam bidang pendidikan yang berarti sejumlah mata pelajaran yang ada di sekolah, perguruan tinggi yang harus ditempuh untuk mencapai suatu tingkat tertentu atau ijazah.

Menurut Undang-Undang Nomor 20 Tahun 2003 tentang Sistem Pendidikan Nasional, kurikulum adalah seperangkat rencana dan pengaturan mengenai tujuan, isi, dan bahan pelajaran serta cara yang digunakan sebagai pedoman penyelenggaraan kegiatan pembelajaran untuk mencapai tujuan pendidikan tertentu (Kemendikbud, 2013). Kurikulum juga merupakan seperangkat rencana yang menjadi pedoman dan pegangan dalam proses pembelajaran (Zaini, 2009). Mengajar (teaching) adalah kegiatan, aktivitas atau perlakuan profesional dari seorang guru, belajar (learning) adalah segala aktivitas dan upaya yang dilakukan siswa sebagai respon terhadap kegiatan mengajar guru. Keseluruhan pertautan kegiatan yang berkenaan dengan terjadinya interaksi pembelajaran disebut pembelajaran (intructions).

Kurikulum 2013 adalah kurikulum pendidikan yang diberlakukan sejak tahun 2013 di Indonesia. Kurikulum 2013 adalah kurikulum yang berbeda dari kurikulum sebelumnya, dimana proses pembelajaran mengedepankan keaktifan siswa dalam mencari, mengolah, menyajikan informasi sendiri. Kurikulum 2013 sesuai KMA nomor 146 tahun 2014 dimaksudkan untuk mengembangkan potensi siswa menuju kemampuan dalam berpikir reflektif bagi penyelesaian masalah sosial di masyarakat.

Matematika pada Kurikulum 2013 menjadi mata pelajaran wajib di tingkat SMP/ MTs termasuk dalam kategori mata pelajaran A, sehingga capaian kompeten- 
sinya secara rinci telah diatur dalam undang-undang. Permendikbud RI Nomor 37 Tahun 2018 menjelaskan berbagai kompetensi yang harus dicapai dalam mempelajari matematika, yaitu kompetensi sikap spiritual, sikap sosial, pengetahuan dan keterampilan. Dalam hal ini perlu dicermati bahwa dalam lingkup kegiatan/ perlombaan maupun olimpiade termasuk di dalamnya KSM, diperlukan kompetensi siswa dalam bidang pengetahuan.

Matematika sesuai sudut pandang kecakapan seseorang menuntut seseorang untuk menggunakan matematika baik sebagai alat maupun gagasan, strategi/teknik masalah-masalah yang berhubungan dengan matematika yang meliputi : pemahaman konsep, pemahaman prosedur, kompetensi strategis, penalaran adaptif dan disposisi produktif. Dalam konteks generalisasi matematika, Harel dan Tall (Dwirahayu, dkk., 2018) membedakannya menjadi tiga (ketiga jenis ini bergantung pada konstruksi mental individu), yaitu generalisasi ekspansif (mampu mengembangkan jangkauan kegunaan skema yang sudah ada tanpa mengkonstruksinya), generalisasi rekonstruktif (dapat mengkonstruksi skema yang sudah ada dengan tujuan untuk memperluas jangkauan penggunaan skema tersebut) dan generalisasi disjungtif (mampu mengkonstruksi skema yang baru dan tidak bergantung pada skema lama dimana skema baru ini dapat digunakan untuk konteks yang baru.

Kompetensi matematika siswa merupakan kompetensi yang berhubungan dengan kemampuan bertanya dan menjawab serta kompetensi yang berhubungan dengan simbolik baik aspek manajemen linguistik maupun aspek manajemen komponen simbolik. Kompetensi Matematika dalam artikel ini meliputi berbagai kompetensi yang berkaitan dengan kompetensi berpikir matematika, mengemukakan dan menyelesaikan masalah metematika, pemodelan matematika dan penalaran matematika. Sedangkan pada kelompok lainnya berkaitan dengan representasi simbol dan formalisme matematika, berkomunikasi dalam matematika, dan pemanfaatan teknologi.

Selain itu, pemahaman terhadap konsep dan kompetensi strategis juga harus dikuasai siswa. Pemahaman konsep (conceptual understanding) dimaksudkan sebagai kemampuan dalam memahami konsep, operasi, dan relasi dalam matematika. Berkaitan dengan pentingnya komponen pemahaman dalam matematika, Sumarmo (Afrilianto, 2012) juga menyatakan visi pengembangan pembelajaran matematika untuk memenuhi kebutuhan masa kini, yaitu pembelajaran matematika perlu diarahkan untuk pemahaman konsep dan prinsip matematika yang kemudian di- 
perlukan untuk menyelesaikan masalah matematika baik dalam disiplin ilmu lain maupun dalam kehidupan sehari-hari. Lebih lanjut dijelaskan oleh Afrilianto bahwa kompetensi strategis (strategic competence) merupakan suatu kemampuan untuk merumuskan, merepresentasikan, serta menyelesaikan permasalahan matematika.

\section{Pembinaan KSM Matematika di Indonesia}

Pelaksanaan Kompetisi Sains Madrasah (KSM) dapat berjalan sukses bagi suatu lembaga pendidikan apabila didukung kompetensi dalam bidangnya. Matematika menjadi salah satu mata pelajaran yang dilombakan dalam KSM merupakan mata pelajaran yang tidak mudah, memerlukan ketelitian dan kecermatan sehingga dalam pencapaiannya diperlukan upaya-upaya dari guru untuk meningkatkan kompetensi siswa melalui pembinaan matematika. Tujuannya, siswa memahami materi dan karakteristik soal-soal olimpiade matematika secara komprehensif, sehingga siswa memiliki kesiapan baik secara materi soal maupun mental dalam bertanding untuk menghadapi event lomba matematika maupun olimpiade matematika.

Pembinaan matematika di Indonesia berdasarkan penelitian terdahulu terbagi dalam beberapa bentuk pembinaan yang berbeda. Meskipun demikian, tujuan dari pembinaan ini masih sama yaitu dalam rangka peningkatan kompetensi siswa dalam mata pelajaran matematika. Pelaksanaan pembinaan olimpiade matematika yang diberikan kepada siswa merupakan suatu rentetan proses pemahaman konsep-konsep dasar matematika secara hirarki. Apabila dalam pelaksanaan pembinaan olimpiade sebelumnya mengalami gangguan atau tidak dapat menyerap materi dengan baik, maka akan terjadi gangguan atau kebuntuan dalam mempelajari konsep yang lebih tinggi.

Pembinaan matematika dapat dilakukan dalam beberapa langkah. Pertama, adalah pembinaan yang umum dilakukan di sekolah-sekolah yaitu dengan memberi soal-soal setara olimpiade yang familiar dan dapat diperoleh dari buku soal-soal olimpiade matematika, contohnya di SMPN 2 Jember dan SD 1 Ungaran Yogyakarta. Pembinaan ini sebenarnya sudah sangat familiar dilaksanakan di sekolah-sekolah, hanya saja penelitian terkait penerapan sistem ini masih sangat sedikit. Implementasi sistem tersebut dilakukan melalui soal-soal test yang diberikan kepada siswa yaitu soal-soal olimpiade matematika yang sangat familiar bagi siswa dan seharusnya sudah menjadi konsep sederhana bagi siswa yang mengikuti 
pembinaan olimpiade matematika (Jana, 2018a).

Kedua, pelaksanaan pembinaan yang terdiri dari tiga tahap meliputi: pre test, treatment, dan post test (Gita, dkk., 2017). Bentuk kegiatan pre test dilakukan dengan pemberian soal diawal untuk mengetahui kemampuan siswa secara umum dan digunakan sebagai pijakan pemberian treatment yang sesuai dengan kondisi siswa. Treatment yang diberikan kepada siswa berupa pemberian materi dan latihan soal-soal olimpiade. Post test merupakan pemberian soal tes untuk mengukur kemampuan siswa dalam mengerjakan soal-soal olimpiade setelah diberikan treatment.

Ketika treatment selesai dilaksanakan, dilanjutkan dengan pemberian soal-soal dengan level yang bertahap, dari mulai yang rendah, sedang, kemudian tinggi. Tujuan dari pemberian tes ini sebagai tolok ukur setelah treathment dan sarana belajar aktif dengan metode diskusi kecermatan pada saat soal dibahas. Pembahasan soal dengan metode diskusi akan mendorong siswa dalam menyampaikan pemahamannya terhadap soal yang telah diberikan. Sehingga guru pembina, pendamping maupun pembimbing dapat meluruskan pendapat jika ada hal yang kurang benar.

Ketika pelaksanaan pre-test siswa dihadapkan dengan soal-soal latihan olimpiade yang familiar sehingga treatment materi disesuaikan dengan standar kemampuan siswa. Treatment ini dalam pelaksanaanya tentu bisa menggunakan berbagai metode yang variatif yaitu, ceramah, diskusi kecil maupun presentasi. Metode ceramah digunakan ketika guru memberikan materi mengenai konsep-konsep dasar matematika, memotivasi semangat siswa dan karakteristik soal-soal olimpiade siswa. Diskusi diterapkan saat siswa telah mendapat materi, kemudian diberikan soal yang sifatnya eksplorasi dan pengembangan. Presentasi dilakukan untuk mengukur kemampuan siswa dalam memecahkan masalah dan mengeksplorasi soal olimpiade tersebut.

Ketiga, pembinaan yang umum dilaksanakan di sekolah-sekolah di Indonesia terutama SMP di Kota Madiun memiliki inisiatif sistem pembinaan yaitu dengan mengadakan study club menjadi sebuah ekstrakulikuler yang rutin di sekolah tersebut (Ariyanti, dkk., 2019). Selain di daerah Kota Madiun ada berbagai sekolah yang telah menerapkan sistem demikian yaitu di MTsN 7 Tulungagung dan MAN 3 Blitar. Kegiatan klub matematika dan IPA ini dilaksanakan seminggu sekali secara rutin. Jika terdapat event khusus seperti KSM, OSN, atau kegiatan olimpiade man- 
diri dalam waktu dekat, maka efektivitas ditingkatkan dengan menambah jam pelajaran studi klub dengan pemberian materi yang lebih padat, dan terarah. Pembinaan tersebut bisa mengacu pada sasaran dengan bentuk pembinaan penguasaan konsep Matematika dalam menyelesaikan soal olimpiade, pelatihan dan pendampingan penggunaan komputer sebagai penambah informasi matematika dan bahan-bahan yang diperlukan seperti soal-soal kompetisi beberapa tahun yang lalu.

Pelaksanaan kegiatan berjalan dengan menggunakan strategi pembelajaran kreatif, pemecahan masalah Matematika dan IPA, tanya jawab interaktif, dan pelatihan internet. Pembelajaran kreatif, pemecahan masalah, dan tanya jawab interaktif digunakan dalam memahami konsep-konsep serta memecahkan masalah yang timbul dalam pemahaman sesuatu yang belum menemukan titik kesamaan persepsi dalam menyelesaiakan soal-soal Olimpiade Sains dan pelatihan internet digunakan untuk memperoleh materi konsep Matematika dan IPA (Ariyanti, dkk., 2019).

Keempat, terdapat sekolah yang membentuk satu kelas formal yang terdiri dari siswa berkompetensi yang siap menerima bimbingan untuk mengikuti kompetisi, seperti bimbingan di SMA Semesta Semarang, baik untuk Kompetisi Sains atau Olimpiade Sains Nasional (OSN) atau olimpiade lokal yang diadakan suatu lembaga dengan nama kelas olimpiade. Manajemen diatur langsung oleh sekolah yang pelaksanaannya melalui berbagai tahapan, yaitu: (1) tahap perencanaan, (2) pelaksanaan, dan evaluasi hasil (Purbonuswanto, 2016).

Adapun pelaksanaan perencanaan pembelajaran menggunakan pendekatan konstruktivisme sebagaimana pembelajaran di sekolah. Tahap perencanaan dilakukan secara teratur dan terencana. Perencanaan dilaksanakan dalam bentuk program tahunan (prota), program semester (promes), silabus, dan RPP. Rencana pembelajaran kontekstual yang dikembangkan oleh paham konstruktivis menekankan pada tahap-tahap kegiatan (yang mencerminkan proses pembelajaran) siswa dan media atau sumber pembelajaran yang dipakai. Tujuan dari perencanaan ini agar guru mampu mengelola pembelajaran sesuai rencana awal, baik mengenai alokasi waktu yang tersedia, maupun metode pembelajaran yang digunakan serta sistem evaluasi hasil pembelajaran yang digunakan.

Pelaksanaan pembelajaran dilakukan di dalam kelas dengan menggunakan strategi olimpiade terpadu. Guru menerangkan materi menyeluruh secara sederhana, menerangkan materi yang ditematikan dengan mengetahui permasalahan di 
dalamnya. Selanjutnya guru cenderung meminta siswa mempraktikkan materi yang telah disampaikan, memberi kesempatan siswa bertanya dan menganalisis permasalahan serta pembelajaran lingkungan sekitar. Guru juga membagi siswa berdasarkan kelompok-kelompok tertentu.

Pelaksanaan evaluasi proses pembelajaran dilakukan secara mandiri oleh guru kelas. Evaluasi proses dilakukan setelah satu kali pembahasan pokok bahasan selesai dari beberapa pertemuan yang dilaksanakan di kelas. Evaluasi hasil belajar pada kelas olimpiade dilakukan dengan tertulis dan praktek sederhana diruang kelas. Hal tersebut dilakukan agar guru mengetahui secara langsung bagaimana kemampuan siswa dalam menerima materi yang ditematikkan. Evaluasi dalam bentuk tertulis dimaksudkan untuk mengetahui kemampuan akademik siswa khususnya mengenai pelajaran yang ditematikkan.

Kelima, pembinaan boleh dilakukan dengan metode yang sama dengan metode-metode diatas, untuk lebih meningkatkan pemahaman siswa dapat dilakukan dengan pengembangan bahan ajar mengenai materi olimpiade. Pengembangan bahan ajar yang dilakukan dapat dibentuk sesuai dengan model pemecahan masalah, sehingga akan meningkatkan kompetensi penalaran matematis siswa (Thohir, 2017). Pemecahan masalah yang digunakan merupakan pemecahan masalah yang dikembangkan berdasarkan model-model pemecahan yang sudah ada sehingga menjadi pemecahan masalah model baru. Model pemecahan masalah ini akan mengarah kepada keaktifan penalaran siswa, pembelajaran teman sebaya (peer teaching), sehingga mendorong siswa aktif memecahkan masalah bersama.

\section{Kesimpulan}

Peningkatan kompetensi siswa pada mata pelajaran matematika melalui Kompetisi Sains Madrasah (KSM) dilaksanakan dengan berbagai pembinaan yang dilaksanakan di masing-masing sekolah di Indonesia. Adapun pembinaan-pembinaan tersebut terdiri dari berbagai bentuk, antara lain:

a. Pembinaan ketat di sekolah-sekolah dengan memberi soal-soal olimpiade yang familiar yang diperoleh dari buku soal-soal olimpiade matematika.

b. Pembinaan melalui pre test, treatment, dan post test. Pre test untuk mengetahui kemampuan siswa secara umum. Treatment yang pemberian materi dan 
latihan soal-soal olimpiade. Terakhir adalah post test yaitu pemberian soal tes untuk mengukur kemampuan siswa setelah treatment.

c. Pembinaan dengan mengadakan study club yang dilaksanakan seminggu sekali secara rutin. Jika terdapat event khusus seperti KSM, OSN atau kegiatan olimpiade mandiri dalam waktu dekat, maka pemberian materi lebih padat, dan terarah.

d. Pembinaan dengan membentuk satu kelas formal yang terdiri dari siswa berkompetensi yang siap menerima bimbingan untuk mengikuti kompetisi dan olimpiade.

e. Pembinaan dengan melakukan pengembangan terhadap bahan ajar sesuai dengan model pemecahan masalah, sehingga akan meningkatkan kompetensi penalaran matematis siswa.

\section{Daftar Pustaka}

Afrilianto, M. (2012). Peningkatan Pemahaman Konsep dan Kompetensi Matematis Siswa SMP dengan Pendekatan Metaphorical Thinking. Infinity Journal 1(2). https:// doi.org/ 10.22460/ infinity.v1i2.19. 192-202.

Ariyanti, G., Rahajeng, R., \& Sumadji, A. R. (2019). Pembinaan Olimpiade Sains Melalui Pemberdayaan Klub Matematika dan IPA Bagi Siswa SMP di Kota Madiun. Jurnal Abdimas BSI: Jurnal Pengabdian Kepada Masyarakat 2(2). https:// doi.org/ 10.31294/ jabdimas.v2i2.5667. 350-358.

Darmawijoyo. 2009. Kompetensi Matematika dalam Perspektif Matematika dan

Pengajarannya. Jurnal Matematika Sriwijaya 3(1). https:/ / doi.org/ 10.22342/jpm.3.1.318.

Direktorat Jenderal Pendidikan Islam RI. 2014. Petunjuk Teknis Kompetisi Sains Madrasah (KSM).

Dwirahayu, G., Kustiawati, D., \& Bidari, I. (2018). Pengaruh Habits of Mind terhadap Kemampuan generalisasi Matematis. Jurnal Penelitian Dan Pembelajaran Matematika, 11(2). https:/ / doi.org/ 10.30870/jppm.v11i2.3757.

Fahrurrozi \& Hamdi, S.. 2017. Metode Pembelajaran Matematika, Selong: Universitas Hamzanwandi Press.

Fathurrohman, Muhammad. 2017. Belajar dan Pembelajaran Modern Konsep Dasar, Inovasi, dan Teori Pembelajaran. Yogyakarta: Garudhawaca. 
Gita, I. N., Suryawan, P. P., \& Artawan, I. G. N. Y. (2017). Pembinaan Olimpiade Matematika bagi Siswa dan Guru di Desa Sambangan. International Journal of Community Service Learning. https:/ / doi.org/ 10.23887/ ijcsl.v1i1.11905

Jana, P. (2018a). Keterampilan Berpikir Kreatif Siswa Dalam Menyelesaikan Soal Olimpiade Matematika Berdasarkan Level Metakognisi. J-Dinamika, 2(2). https:/ / doi.org/ 10.35316/ alifmatika.2019.v1i1.1-14.1-14.

Jana, P. (2018b). Peningkatan Kompetensi Siswa SMP di Kota Bengkulu melalui Penerapan Model Pembelajaran Matematika (MPM-SMP). J-Dinamika, 2(2). https:// doi.org/ 10.31186/jpmr.v2i1.3102.46-62.

Kemendikbud. (2013). UU SISDIKNAS Nomor 20 Tahun 2003. KEMENDIKBUD.

Permendikbud No.35 Tahun 2018 tentang Kurikulum 2013 Sekolah Menengah Pertama/ Madrasah Tsanawiyah, Jakarta.

Purbonuswanto, W. (2016). Pengelolaan Kelas Olimpiade Di SMA Semesta Semarang. Jurnal Pendidikan Dasar Universitas Sebelas Maret, 4(2). 119-138.

Wiyoko, T., Megawati, M., Aprizan, A., \& Avana, N. (2019). Peningkatan Kompetensi Siswa Melalui Pembinaan Olimpiade Sains (OSN). Warta LPM, 22(2). https:// doi.org/ 10.23917/ warta.v22i2.8619.67-75.

Zaini, Muhammad. 2009. Pengembangan Kurikulum. Yogyakarta: Penerbit Teras. 